\title{
Maternal and Child Health Services and Urban Economics
}

\author{
MATTHEW TAYBACK, Sc.D., and HELEN WALLACE, M.D.
}

\begin{abstract}
A SQUEEZE brought about by a decline in economic capability and an increase in public obligation is characteristic of many of the older major cities in the United States. It is shown in bold relief for Baltimore in table 1 . This paper is concerned with the major problems in maternal and child health administration resulting from this squeeze and the solutions which appear to be appropriate. The paper will first present details of the economic position and maternal and child health needs for Baltimore, then the results of a survey of maternal and child health needs in the major cities of the country, and, finally, suggestions for relief.
\end{abstract}

\section{Public Obligation}

With the increase in number of public school children the need to provide appropriate and basic school health services has risen accordingly. In Baltimore in 1950 there were 118,000 students registered in the public schools, or 12 percent of the total population of the city. By 1960 the number of students registered had risen to 163,000 , a substantial increase numerically at a time when the total population of

Dr. Tayback is assistant commissioner of health, Baltimore City Health Department, Baltimore, Md., and Dr. Wallace is professor of maternal and child health, School of Public Health, University of California, Berkeley. At the time of the study Dr.Wallace was chief of the Child Health Studies Branch, Children's Bureau, Department of Health, Education, and Welfare, Washington, D.C. the city was declining. About one out of every six residents, approximately 17 percent of the population, was a student in the public schools.

The number of medically indigent mothers is difficult to determine accurately. However, in Baltimore a central maternity information and referral service provided by the Baltimore City Health Department (1) administers a modified means test for registration and care in the department's free prenatal care clinics. Thus, the extent of registration of mothers in these clinics is an index of medical indigency and a measure of the public obligation for maternity care, including prenatal, delivery, and postnatal services. In 1950 the number registered in the free prenatal care clinics of the health department was 2,411 , or 1 per 9 live births. The number registered in 1960 was 5,612 , an increase of 133 percent or 1 per 4 live births.

The trend in the number of medically indigent children can be approximated by two different methods. One can reason that this trend percentagewise would follow that which can be described for indigent children, that is, those covered by public assistance in the aid to dependent children, foster care, and general public assistance categories. If one pursues this logic, the relevant data are that in 1950 there were 13,992 such children and by 1960 this group had increased to 21,570 , an increase of 55 percent, which is one estimate of the relative rise in medical indigency. Or we might take as a criterion of medical indigency a family income which is 40 percent or more below the Bureau of Labor Statistics established estimate 
for a "modest but adequate" level of living. If this is done, one obtains the estimates that in 1950 there were 33,859 medically indigent families, which had increased by 54 percent in 10 years to 52,152 . If one assumes a constant number of children per family, this would indicate that the number of medically indigent children had also increased by 54 percent. We obtain then from the two methods the impression that there has been an increase in the number of medically indigent children within the general range of 55 percent.

Further evidence of the growth in public obligation for maternal and child health services can be found by noting from table 1 the increase of 41 percent in illegimate babies, of 59

Table 1. Major economic and maternal and child health indices, Baltimore, Md., 1950-60

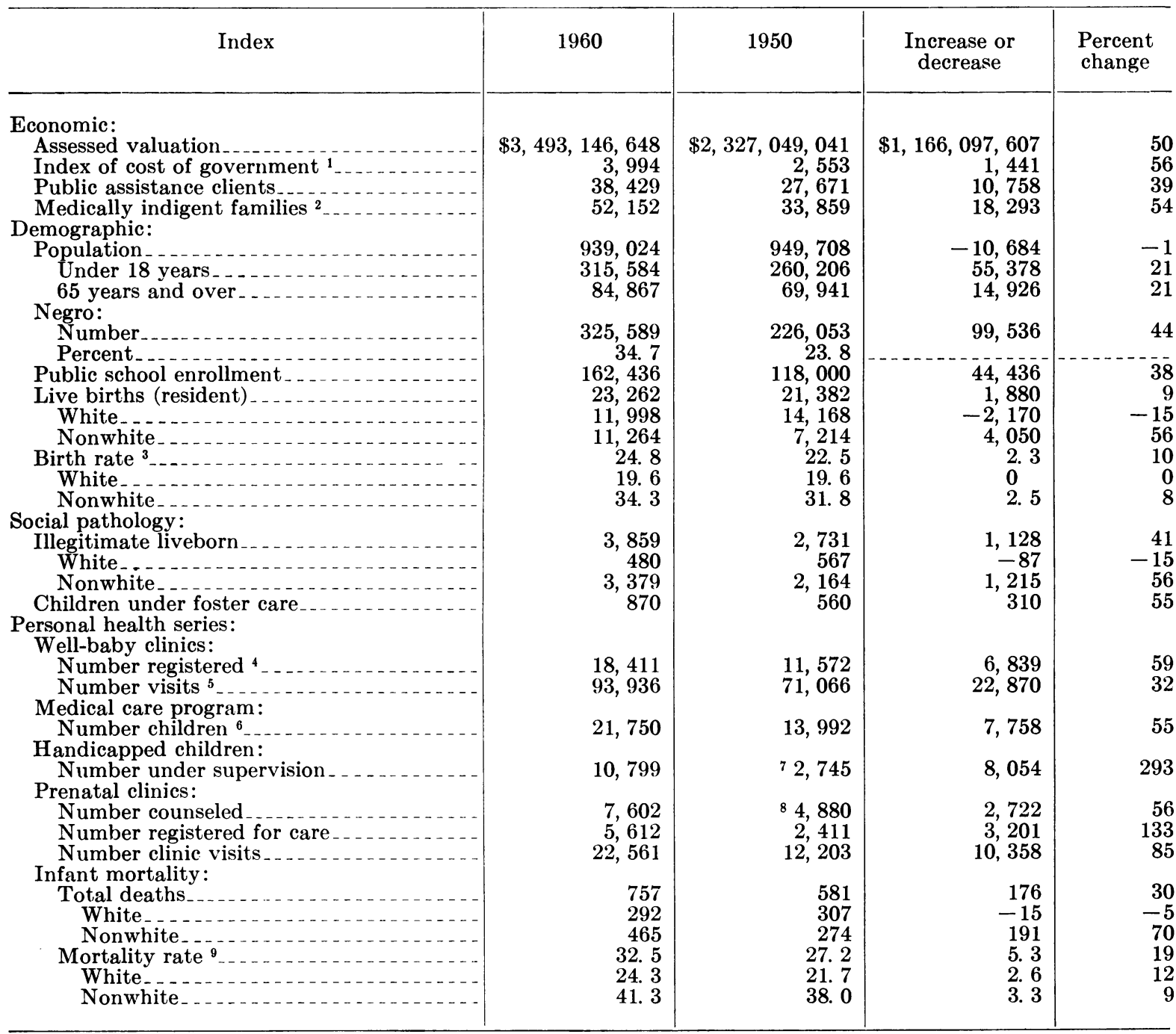

1 Index of cost of government is obtained by computing the mean of the minimum salaries established for the positions of teachers, policemen, firemen, senior clerks, and public health nurses.

2 Income figures which would allow for a "modest but adequate" level of living in Baltimore for 1960 and 1950 for a four-member family were obtained from the Monthly Labor Review published by the Bureau of Labor Statistics. These figures were $\$ 5,718$ in 1960 and $\$ 3,773$ in 1950 . An income equivalent to 60 percent of these figures was taken to be that below which a family could be considered to be medically indigent, that is, an income below $\$ 3,400$ for 1960 and below $\$ 2,300$ for 1950 .

${ }^{3}$ Per 1,000 population.

${ }_{4}$ Under 1 year.

5 All ages.

6 Under 15 years.

7 First full year of program.

8 First year of counseling.

${ }^{9}$ Per 1,000 live births. 
percent in registrations at well-baby clinics, of 19 percent in infant mortality, and of 55 percent in children under foster care.

\section{Public Capacity To Support Services}

It could be argued that the dramatic increase in public obligation for maternal and child health services is not a problem in itself if there is a parallel increase in economic capacity to meet this obligation. But this has not occurred.

The index of cost of government (table 1) was $\$ 2,553$ in 1950 and $\$ 3,994$ in 1960 , an increase of 56 percent. The following figures represent the average beginning salaries of the basic employees of a local government and have been used to compute an index of cost of government:

\begin{tabular}{|c|c|c|}
\hline & 1960 & 1950 \\
\hline & $\$ 4,40$ & ${ }^{1} \$ 2,475$ \\
\hline & & ${ }^{i} 2,875$ \\
\hline$-----\ldots-$ & 4,500 & 2 \\
\hline ks & & 2,40 \\
\hline blic health nurses & 3,492 & 2,400 \\
\hline
\end{tabular}

${ }^{1}$ Salaries adjusted to 1960 workweek.

If the responsibilities of government had remained stationary, an increase in revenue of 56 percent would have been necessary. Capacity to raise revenue at a local level generally depends upon the assessed valuation of property, which in Baltimore rose 50 percent at a time when the index of cost of government rose by 56 percent, leaving a relative deficit in revenue capacity versus obligation for a fixed govermment program. 'The fact is that Baltimore has found it barely possible to support a 1950 level of service. Without new sources of fiscal support or heroic changes in property taxes, which can be economically damaging to the city as a corporate structure competing with surrounding suburbs for industrial development, the city cannot meet the requirements of 1960 levels of service created by a rapidly increasing component of economically depressed persons.

\section{Survey of $\mathrm{MCH}$ Needs}

It has been apparent for some time that many of the large cities in the United States have been undergoing demographic changes which have resulted in heavier demands for provision of personal health services by health departments. One program area which has felt these increased demands has been maternal and child health. Because facts have not been available to portray a composite large-city picture of the health status of mothers and children and of health services for them, it was deemed necessary to survey the large cities in order to collect such information.

Method of study. During the fall of 1961 a questionnaire was distributed by the president of the United States Conference of City Health Officers to the health commissioners of the 61 cities with a total population of 200,000 or more, according to the 1960 census. Replies were received from 40 cities, or 66 percent (table 2 ). The data provided in the replies form the basis of this section of the paper.

Mortality among mothers and children. A

Table 2. Number and percent of cities ${ }^{1}$ with one or more full-time physicians in maternal and child care programs, United States, 1961

\begin{tabular}{|c|c|c|c|c|c|c|}
\hline \multirow{3}{*}{ Size of city } & \multirow{3}{*}{$\begin{array}{l}\text { Number of } \\
\text { cities } \\
\text { queried }\end{array}$} & \multicolumn{5}{|c|}{ Respondents } \\
\hline & & \multirow{2}{*}{ Total } & \multicolumn{2}{|c|}{$\begin{array}{l}1 \text { or more full-time } \\
\text { physicians }\end{array}$} & \multicolumn{2}{|c|}{$\begin{array}{l}\text { Fewer than } 1 \text { full-time } \\
\text { physician }\end{array}$} \\
\hline & & & Number & Percent ${ }^{2}$ & Number & Percent ${ }^{2}$ \\
\hline $\begin{array}{l}1 \text { million and over } \\
500,000-999,000 \\
250,000-499,000 \\
200,000-249,000\end{array}$ & $\begin{array}{r}5 \\
16 \\
30 \\
10\end{array}$ & $\begin{array}{r}3 \\
12 \\
20 \\
5\end{array}$ & $\begin{array}{r}3 \\
8 \\
11 \\
3\end{array}$ & $\begin{array}{r}100 \\
67 \\
55 \\
60\end{array}$ & $\begin{array}{l}0 \\
4 \\
9 \\
2\end{array}$ & $\begin{array}{r}0 \\
33 \\
45 \\
40\end{array}$ \\
\hline
\end{tabular}

1200,000 or more population.

2 Percent of respondent cities. 
significant percentage of respondent cities reported mortality rates in mothers and children higher than the 1959 rates for the United States as a whole. In descending order, the highest percentages of respondent large cities with mortality rates above the 1959 rate for the United States were:

\begin{tabular}{|c|c|}
\hline Mortality rate & $\begin{array}{c}\text { Percent above } \\
1959 \text { average for } \\
\text { United States }\end{array}$ \\
\hline Children 5-9 years & - 68 \\
\hline Neonatal & 63 \\
\hline Children 1-4 years & 62 \\
\hline Infant_-_- & 55 \\
\hline Children 10-14 years & 55 \\
\hline Maternal & 44 \\
\hline Fetal & 38 \\
\hline Postneonatal & 32 \\
\hline Youths 15-19 years & 25 \\
\hline
\end{tabular}

Maternity and newborn care. Fifteen cities provided data on the percentage of live births among women who had had no prenatal care. Six cities reported that 10 percent or more of women delivering live babies failed to receive prenatal care. The remaining cities reported the percentage delivered without prenatal care to be 5 or less.

Most of the cities responding to the questionnaire reported their incidence of prematurity and live births out of wedlock to be above the average for the United States for 1959. Twenty-four of 34 cities reported a high incidence of prematurity, and 25 of 32 cities, a high incidence of live births out of wedlock (table 3). This was true for both white and nonwhite groups.

Table 4 shows the percentage of premature and out-of-wedlock births in the United States in 1959 and the high and low percentages for the 40 large cities.

Infant and preschool services. Twenty cities reported that from one-quarter to one-half
Table 4. Percentage of premature and out-ofwedlock births in 40 large cities, according to race, United States, 1959

\begin{tabular}{|c|c|c|c|c|c|c|}
\hline \multirow{2}{*}{ Rate } & \multicolumn{3}{|c|}{ Premature } & \multicolumn{3}{|c|}{ Out-of-wedlock } \\
\hline & Total & White & $\begin{array}{l}\text { Non- } \\
\text { white }\end{array}$ & Total & White & $\begin{array}{l}\text { Non- } \\
\text { white }\end{array}$ \\
\hline United States ${ }^{1}$ & 7. 8 & 6. 8 & 12.9 & 5. 2 & 2. 2 & 21. 8 \\
\hline $\begin{array}{l}\text { Cities: } \\
\text { High } \\
\text { Low }\end{array}$ & $\begin{array}{r}12.4 \\
6.3\end{array}$ & $\begin{array}{r}10.0 \\
6.5\end{array}$ & $\begin{array}{l}17.0 \\
10.5\end{array}$ & $\begin{array}{r}19.8 \\
3.8\end{array}$ & $\begin{array}{l}\text { 5. } 4 \\
\text { 1. } 1\end{array}$ & $\begin{array}{l}32.0 \\
12.2\end{array}$ \\
\hline
\end{tabular}

1 Based on all live births in 1959.

of all infants received health supervision from the community well-child conferences in 1960:

Percent of infants served
Below 10
$10-19$
$20-29$
40
40

Number of cities 7

9
9
8
4
0
1
2

Eleven cities reported a waiting list and 15 cities reported a waiting period for infants and children applying for health supervision at well-child conferences. The longest waiting list was for 1,224 infants and children and the longest waiting period was 3-12 months.

While many cities were not able to provide data on immunization status of children under 5 years of age, approximately one-half of the cities providing such data reported that less than 70 percent of the infants and children had been immunized against poliomyelitis and smallpox (table 5).

Services for handicapped children. Seventeen cities reported a lack of or inadequate

Table 3. Incidence of premature and out-of-wedlock births per 1,000 live births, 40 large cities compared with United States average, by race, 1959

\begin{tabular}{|c|c|c|c|c|c|c|}
\hline \multirow{2}{*}{ Average } & \multicolumn{3}{|c|}{ Premature } & \multicolumn{3}{|c|}{ Out-of-wedlock } \\
\hline & Total & White & Nonwhite & Total & White & Nonwhite \\
\hline $\begin{array}{l}\text { Above United States } \\
\text { Same as United States } \\
\text { Below United States. } \\
\text { Data not available. }\end{array}$ & $\begin{array}{r}24 \\
1 \\
9 \\
6\end{array}$ & $\begin{array}{r}20 \\
1 \\
3 \\
16\end{array}$ & $\begin{array}{r}16 \\
0 \\
8 \\
16\end{array}$ & $\begin{array}{r}25 \\
1 \\
6 \\
8\end{array}$ & $\begin{array}{r}24 \\
1 \\
3 \\
12\end{array}$ & $\begin{array}{r}17 \\
1 \\
10 \\
12\end{array}$ \\
\hline
\end{tabular}


services for the diagnosis, treatment, and rehabilitation of children with malocclusion; 15 cities, for emotionally disturbed children; 11 cities, for children with epilepsy or with mental retardation; 8 cities, for children with hearing and speech disorders; and 7 cities for children with visual conditions. More adequate coverage was reported for children with orthopedic conditions, cleft palate, rheumatic fever and rheumatic heart disease, or congenital heart disease.

Administrative services. Annual per capita expenditures for health services for mothers and children by the local official health agencies ranged from $\$ 2.09$ to 4 cents. Twenty-seven (82 percent) of the 33 cities which reported data spend less than 60 cents per capita for these services, and of these, 12 cities (36 percent) spend less than 30 cents per capita. The mean per capita expenditure was 49 cents and the median 35 cents.

Sixty-three percent of the respondent cities provide at least one full-time physician employed in maternal and child health and child care services. All the respondent cities with a population of 1 million and over do so, while 60 percent of the cities of 200,000 through 999,999 population do so (table 2 ).

Major unmet needs. The tabulation presents the major unmet needs in maternal and child health reported by the respondent cities. In terms of frequency, the need for increased funds and additional personnel head the list. Needs

Table 5. Distribution of $\mathbf{4 0}$ reporting cities according to percentage of children under 5 years of age receiving DPT, poliomyelitis, and smallpox vaccine, 1960

\begin{tabular}{|c|c|c|c|}
\hline \multirow{2}{*}{$\begin{array}{l}\text { Percent of children } \\
\text { vaccinated }\end{array}$} & \multicolumn{3}{|c|}{ Number of cities } \\
\hline & DPT & $\begin{array}{l}\text { Poliomy- } \\
\text { elitis }\end{array}$ & Smallpox \\
\hline $\begin{array}{l}10-19 \\
20-29 \\
30-39 \\
40-49 \\
50-59 \\
60-69 \\
70-79 \\
80-89 \\
90-99 \\
\text { Data not available }\end{array}$ & \begin{tabular}{r}
-1 \\
$-\cdots$ \\
\hdashline \\
9 \\
3 \\
3 \\
22
\end{tabular} & \begin{tabular}{r}
1 \\
- \\
\hdashline \\
3 \\
4 \\
6 \\
3 \\
0 \\
21
\end{tabular} & $\begin{array}{r}- \\
2 \\
- \\
4 \\
1 \\
3 \\
1 \\
5 \\
22\end{array}$ \\
\hline
\end{tabular}

for both specific preventive and treatment services were reported by the 40 large cities, as follows:

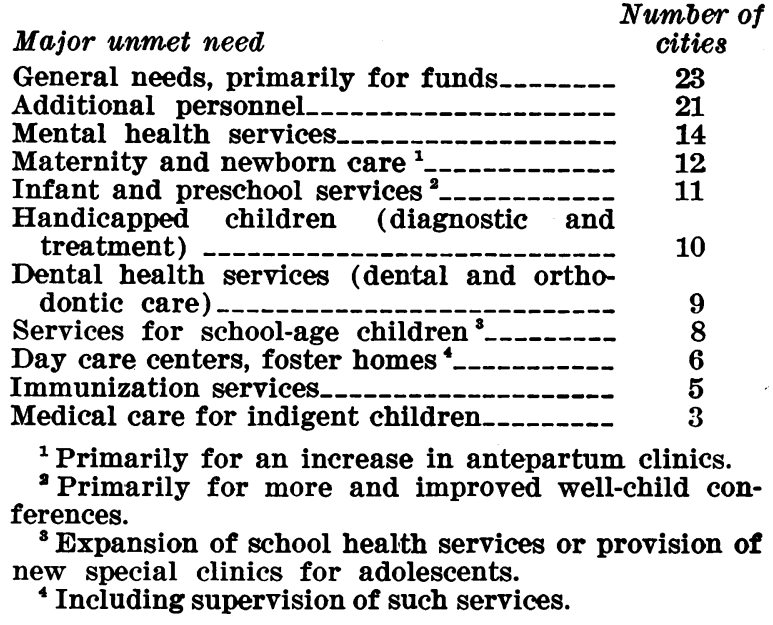

\section{Discussion}

The foregoing data may be briefly summarized as follows:

- A considerable percentage of the respondent large cities reported their maternal, infant, and childhood mortality rates to be above these rates for the United States as a whole.

- Six of 15 reporting cities reported that 10 percent or more of all infants were delivered of mothers who had had no prenatal care.

- Most respondent cities reported their incidence of prematurity to be higher than that of the United States as a whole.

- Twenty-five of 32 reporting cities reported that their percentage of out-of-wedlock births was higher than that of the United States as a whole.

- Registration of infants in well-child conferences in the large cities is high, and there are significant numbers of infants awaiting registration.

- Approximately one-half of the large cities reported that less than 70 percent of infants and children under 5 years of age have been vaccinated against poliomyelitis and smallpox.

- Many cities reported inadequate diagnostic, treatment, and rehabilitation services, or lack of them, for handicapped children, especially those with malocclusion, emotional disturbance, epilepsy, mental retardation, and hearing, speech, and visual impairments. 
It is clear that there is an expressed need to strengthen and expand antepartum clinic services, well-child conferences, health services for children of school age, including special clinics for adolescents, and mental health services. It is significant that these represent the basic preventive services which form the cornerstone of health in any community. When these are of insufficient quantity and quality, this is likely to be reflected in a rise in the mortality rates. At the same time morbidity, both acute and long term, of a preventable nature may continue to occur or to increase. Thus, there may be both a continuation of loss of life and of preventable illnesses; the latter, in particular, place even heavier demands upon the community.

In addition to the increased need for the basic preventive services, the large cities have expressed needs for certain other services: diagnostic, treatment, and rehabilitation services for handicapped children, including those with behavior problems; dental and orthodontic care; and medical care of indigent children. These services represent the therapeutic part of the community service spectrum. It would be hoped that, as our preventive techniques are expanded and improved, there may be less demand for treatment or rehabilitation services.

The large cities of the United States are currently affected by a series of factors tending to aggravate their health problems in maternal and child health. The continuing high birth rate has placed increased demands upon hospitals and health personnel, and this has resulted in an increase in the child population requiring health services. At the same time, population shifts have magnified the problem. These shifts include a rural-to-urban migration, an influx of low-income families, with their increased need for publicly funded health and hospital services, and an exodus of middle-income families-families who can support health and hospital services-from the cities to the suburbs. Thus, the environment of a large city is fertile for the proliferation of health problems and of the need for services to control them.

It is evident that increased support for health services in the large cities is required. The most feasible source or sources of such sup- port is a basic issue. It is unlikely that voluntary health agencies can be looked upon as a possibility for significantly increased health services in the large cities. The reason is that maternal and child health services, including school health services, are no longer supported by voluntary funds of significant amount. Increased local taxation is not likely to be a good source of support for health services because this generally results in a higher property tax, thus placing the city in an economically disadvantaged position with respect to the immediate suburban areas so far as commercial development is concerned. This then leaves two other possible sources of support, State or Federal tax funds.

It is conceivable that State tax funds represent a possible source of increased support of health services in the larger cities. However, there is a successful pattern for meeting the maternal and child health needs of economically poorer areas-the Federal program of grantsin-aid to the States under title V of the Social Security Act. It would appear that an expeditious solution to the problems discussed in this paper could be brought about by provision of grants-in-aid for maternal and child health services in the large cities. It is suggested that, among other criteria, such grants be in proportion to the extent of medical indigency as determined by some reasonable formula.

The question of how much per capita expenditure constitutes adequate local expenditure of funds for maternal and child health in the large cities cannot be answered at this time. Nor is there an answer to the question of the proportion of funds to be allocated for preventive versus therapeutic services in maternal and child health. Such information is needed. Perhaps the study of community health services about to be begun by the National Commission on Community Health Services (2) will provide answers to these questions.

For a considerable percentage of the cities studied, the unavailability of such basic program data as immunization levels for communicable disease control, level of prenatal care, and so on, is significant. This lack of medical intelligence represents a serious deficiency in the administration of public health. 


\section{Summary}

This report describes some of the pertinent facts regarding demography, health needs, and health services for mothers and children in the large cities of the United States. There is considerable evidence that a substantially increased requirement for such services has developed, and that these cities require special assistance if demands are to be met. Health leaders in large cities have expressed need for an increase in both preventive services (antepartum clinics, well-child conferences, school health services, and immunization programs), and therapentic services (diagnostic and rehabilitation services for handicapped children, dental and orthodontic care, and medical care of indigent children). Considering the scope of the health problems faced by large cities, Federal funds administered by the Children's Bureau represent the most likely source of support for maternal and child health needs.

\section{REFERENCES}

(1) Hardy, J., et al.: Prenatal interviewing service. Baltimore Health News 34: 182-192, November 1957.

(2) Bauer, T. J. : Appraisal of the Community Health Services and Facilities Act of 1961. Pub. Health Rep. 77 : 561-562, July 1962.

\section{Proposed Regulations on Drug Trials}

Regulations that would strengthen control over clinical trials of new drugs were proposed by Secretary of Health, Education, and Welfare Anthony J. Celebrezze on August 9, 1962.

The proposed regulations would require that clinical investigations be based on adequate preclinical studies to assure safety, that the Food and Drug Administration be notified and given full details of the distribution of drugs for investigations, that clinical investigations be planned properly and executed by qualified investigators, and that the FDA be kept fully informed of the progress of clinical investigations.

If substantial doubt about the safety of a drug develops during clinical investigation, the regulations would require immediate notification of the FDA and all investigators. If necessary, the FDA would halt the trials. Also, if the plan for an investigation proves to be inadequate to assure safety or if the plan as presented is not being followed, FDA could require corrective action or, if necessary, terminate the study.

Secretary Celebrezze said that the new regulations were drawn up with the intention of avoiding unnecessary restrictions on the conduct of research while assuring that the public will be fully protected.

The proposed regulations were published with an invitation to all interested persons to comment on them within 60 days. 


\section{Homemakers}

The number of health or welfare agencies employing homemakers has increased by 43 percent since 1958. An October 1961 survey by the Department of Health, Education, and Welfare indicates that 208 public or voluntary agencies in 40 States, the District of Columbia, and Puerto Rico employed some 2,700 homemakers. Results of the survey are reported in the 1961 "Directory of Homemaker Services" (Public Health Service Publication No. 928).

The homemakers, women specially trained and skilled in homemaking, help maintain family life in the face of illness, death, or other problems. At the time of the survey they were caring for approximately 5,500 families per month, providing each with an average of about 52 hours of care.

Nearly 70 percent of the homemaker services listed in the 1961 directory are administered by voluntary agencies. All 66 public agencies with homemaker services are welfare agencies, including one combined health and welfare agency. Nearly a third of all the agencies provide homemaker services only to families with children, but a majority care for both families with children and adult families.

Some agencies offer variants of regular homemaker services. A county welfare department in North Carolina provides homemaker help during summer months for families of migrant farmworkers. One agency employs a homemaker who is blind to teach newly blinded persons how to regain independent functioning in the home. In other agencies, particularly in the south and west, homemakers conduct classes in homemaking techniques, infant and child care, or home care of invalids.

Distribution of homemaker agencies, homemakers employed and families served, October 1961

\begin{tabular}{|c|c|c|c|c|c|c|c|c|c|}
\hline State $^{1}$ & $\begin{array}{c}\text { Agen- } \\
\text { cies }\end{array}$ & $\begin{array}{l}\text { Com- } \\
\text { muni- } \\
\text { ties }^{2}\end{array}$ & $\begin{array}{c}\text { Home- } \\
\text { mak- } \\
\text { ers }\end{array}$ & $\underset{\text { lies }}{\text { Fami- }}$ & State $^{1}$ & $\begin{array}{c}\text { Agen- } \\
\text { cies }\end{array}$ & $\begin{array}{l}\text { Com- } \\
\text { muni- } \\
\text { ties }^{2}\end{array}$ & $\begin{array}{c}\text { Home- } \\
\text { mak- } \\
\text { ers }\end{array}$ & $\underset{\text { lies }}{\text { Fami- }}$ \\
\hline Alaska $\ldots \ldots$ & 1 & 1 & 2 & 6 & Mississippi_ & 10 & 10 & 10 & \\
\hline Arizona & 2 & 2 & 6 & 34 & Missouri _. & 7 & 4 & 51 & \\
\hline Arkansas.............. & $\overline{1}$ & $\overline{1}$ & 2 & 2 & Montana. & 2 & 2 & 5 & \\
\hline California__ & 12 & 9 & $11 \overline{6}$ & 289 & Nebraska & 2 & 2 & 14 & 140 \\
\hline Colorado - - & 9 & 8 & 29 & 90 & New Hampshire........ & $\overline{3}$ & $\overline{3}$ & 15 & 40 \\
\hline Connecticut_. & 13 & 11 & 115 & 187 & New Jersey & 18 & 18 & 484 & 66 \\
\hline Delaware & 1 & 1 & 4 & 8 & New York & 324 & 410 & 678 & 1,10 \\
\hline District of Columbia & 1 & 1 & 20 & 39 & North Carolina & 14 & 13 & 47 & 32 \\
\hline Florida_... & 4 & 3 & 106 & 164 & Ohio & 12 & 7 & 226 & 64 \\
\hline Georgia _.... & 3 & 2 & 11 & 19 & Oklahoma_............. & 1 & 1 & 3 & \\
\hline Hawaii...... & 1 & 1 & 4 & 4 & Oregon & 1 & 1 & 6 & \\
\hline Illinois & 6 & 3 & 93 & 142 & Pennsylvania. & 14 & 8 & 110 & 250 \\
\hline Indiana_.... & 5 & 4 & 35 & 62 & Puerto Rico & 1 & 1 & 36 & \\
\hline Iowa $\ldots \ldots$ & 1 & 1 & 4 & 4 & Rhode Island & 2 & 2 & 28 & \\
\hline Kansas_...... & 2 & 2 & 3 & 5 & South Dakota & 1 & 1 & 8 & \\
\hline Kentucky _... & 1 & 1 & 13 & 14 & Tennessee & 2 & 2 & 8 & \\
\hline Louisiana $\ldots . .$. & 1 & 1 & 4 & 5 & Texas & $\overline{5}$ & $\overline{4}$ & 39 & 12 \\
\hline Maine _. ..... & 1 & 1 & 10 & 13 & Virginia_... & 1 & 1 & 8 & \\
\hline Maryland . . . . & 2 & 1 & 24 & 32 & West Virginia & 1 & 1 & 2 & \\
\hline Massachusetts $\ldots \ldots$ & 7 & $\mathbf{5}$ & 139 & 265 & Wisconsin & 5 & 1 & $4 \overline{6}$ & 281 \\
\hline $\begin{array}{l}\text { Michigan } \\
\text { Minnesota }\end{array}$ & $\begin{array}{l}4 \\
4\end{array}$ & 3 & 40 & $\begin{array}{l}82 \\
77\end{array}$ & 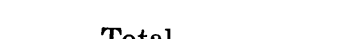 & & & & \\
\hline 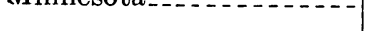 & & & 00 & 77 & J & 208 & 158 & 2,664 & 5,454 \\
\hline
\end{tabular}

1 Alabama, Idaho, Nevada, New Mexico, North Dakota, South Carolina, Utah, Vermont, West Virginia, and Wyoming had no homemaker programs.

2 Number of different cities or towns where agency headquarters are located.

3 One New York City agency with 3 branch offices is counted as 1 agency.

4 Branch offices of $1 \mathrm{New}$ York City agency are located in 2 additional places. 